\title{
Prolongation of the QT Interval Observed in a Japanese Patient with Vivax Malaria Following Treatment with Halofantrine
}

\author{
Shigeyuki $\mathrm{KANO}^{1)}$, Akihiro HAYASHI ${ }^{2)}$, Tsugiyasu KANDA ${ }^{3)}$ \\ and Mamoru SUZUKI ${ }^{1)}$ \\ ${ }^{1}$ Department of Parasitology, Gunma University School of Medicine \\ ${ }^{2}$ Department of Gastroenterology, National Nishi-Saitama Chuo Hospital \\ ${ }^{3}$ Department of Laboratory Medicine and Clinical Laboratory Center, \\ Gunma University School of Medicine \\ (Received: July 27, 1995) \\ (Accepted: September 7, 1995) \\ Key words: halofantrine, malaria, QT prolongation
}

\section{Introduction}

In 1992, some 90 countries or territories where $42 \%$ of the world's population resided were considered malarious and estimation of deaths from malaria worldwide per year were in the order of 1.4 of 2.8 million $^{1)}$. The higher the number of Japanese who go abroad becomes (the total number in 1994 was 13,578,934: Records of Statistical Division of the Ministry of Justice), the greater is the risk of their contracting malaria. Indeed, the reported annual number of imported malaria cases increased to not less than $100^{2}$. Now, malaria should first be presumed if a patient complains of a high fever after a visit to a tropical country. And the importance of instituting prompt diagnosis and proper treatment should also be stressed.

One of the antimalarials which has been highlighted for its effectiveness is halofantrine. This drug has been used for treatment of human malaria since $1984^{3)}$, and to date clinical trials have involved about 3.4 million patients in more than 30 countries (personal communication). Several patients successfully treated with halofantrine without any treatment failure have also been documented in Japan ${ }^{4) ~ 8)}$. However, in 1993, a clinical study involving 400 patients on the ThaiBurmese border revealed cardiac effects of antimalarial treatment with halofantrine, including one sudden death after the treatment ${ }^{9}$. There have also been some spontaneous reports of serious ventricular dysrythmiasis with prolongation of the QT intervals, rarely associated with death ${ }^{10) \sim 12)}$. The pharmaceutical company producing Halfan ${ }^{\circledR}$ has reported 8 cardiac arrests, leading to 6 deaths, when a higher dose than recommended was used, there was recent or concomitant treatment with mefloquine, there was pre-existing prolongation of the QT interval or the patient had a thiamine deficiency. Finally, the World Health Organization (WHO) announced a "drug alert" on halofantrine advising a change in recommendations for its use $\mathrm{e}^{13)}$. In the present paper, we discuss the first Japanese vivax malaria patient whose QT interval was prolonged after treatment with halofantrine.

\section{Case Report}

The patient was a 22-year-old Japanese male college student, who was in India and Thailand

Correspondence to : Shigeyuki KANO, M.D.

Department of Parasitology, Gunma University School of Medicine, 3-39-22, Showa-machi, Maebashi-shi, Gunmaken, 371, Japan 
from July 23 to August 31, 1994. He complained of fever $\left(40^{\circ} \mathrm{C}\right)$ with watery diarrhoea on September 8, and was admitted to National Nishi-Saitama Chuo Hospital on the following day. He was then suspected of contracting dysentery and was treated with an antibiotic. Although he recovered from his diarrhoea soon after the drug therapy, he was still showing fever, chills and sweating every other day. Non-steroidal anti-inflammatory drugs (NSAID) were vainly administered on September 10, 14, 16, and 18, until Plasmodium (P.) vivax was detected in his peripheral blood smear by microscopical observation at a parasitemia of $0.5 \%$ of red blood cells. Antibody titration by the indirect fluorescent antibody test (IFAT) also supported the diagnosis (anti- $P$. vivax antigen titer $=1: 1024$, anti- $P$. falciparum antigen titer $=1: 4$, on Sept. 18). Two tablets each of Halfan ${ }^{\circledR}$ (halofantrine hydrochloride $233 \mathrm{mg}$ base/tab) were administered orally at $12: 00,18: 00$ and $24: 00$ on September 20, with the informed consent of the patient. The clinical course of $P$. vivax parasitemia, body temperature, hematological data, and IFAT titers is shown in Fig. 1. His temperature became normal within 9 hours of the first administration of 2 tablets of Halfan ${ }^{\circledR}$ (21:00 on September 20), and P. vivax parasites had disappeared by September 23 . He was then treated with primaquine $(15 \mathrm{mg} /$ day for 14 days), and no relapse occurred after the treatment. Hematological recovery was already noted on September 26, and the patient was discharged from the hospital on October 3.

The patient was monitored by electrocardiography (ECG) from one day before Halfan ${ }^{\circledR}$ administration (Sept. 19) until the day of his discharge (Oct. 3). Although he seemed to be successfully treated without any complaints of side effects of the drug, cardiac effects of halofantrine were recognized on the ECG. The QT interval was observed to be prolonged on September 21 and 22 (0.52 sec.) (Fig. 2), and became normal by September $26(0.40 \mathrm{sec}$.) (Fig. 3). Sporadic arrythmia was also detected on September 21. However, the QRS interval was unaffected by the drug.

Fig. 1 Clinical course of the disease

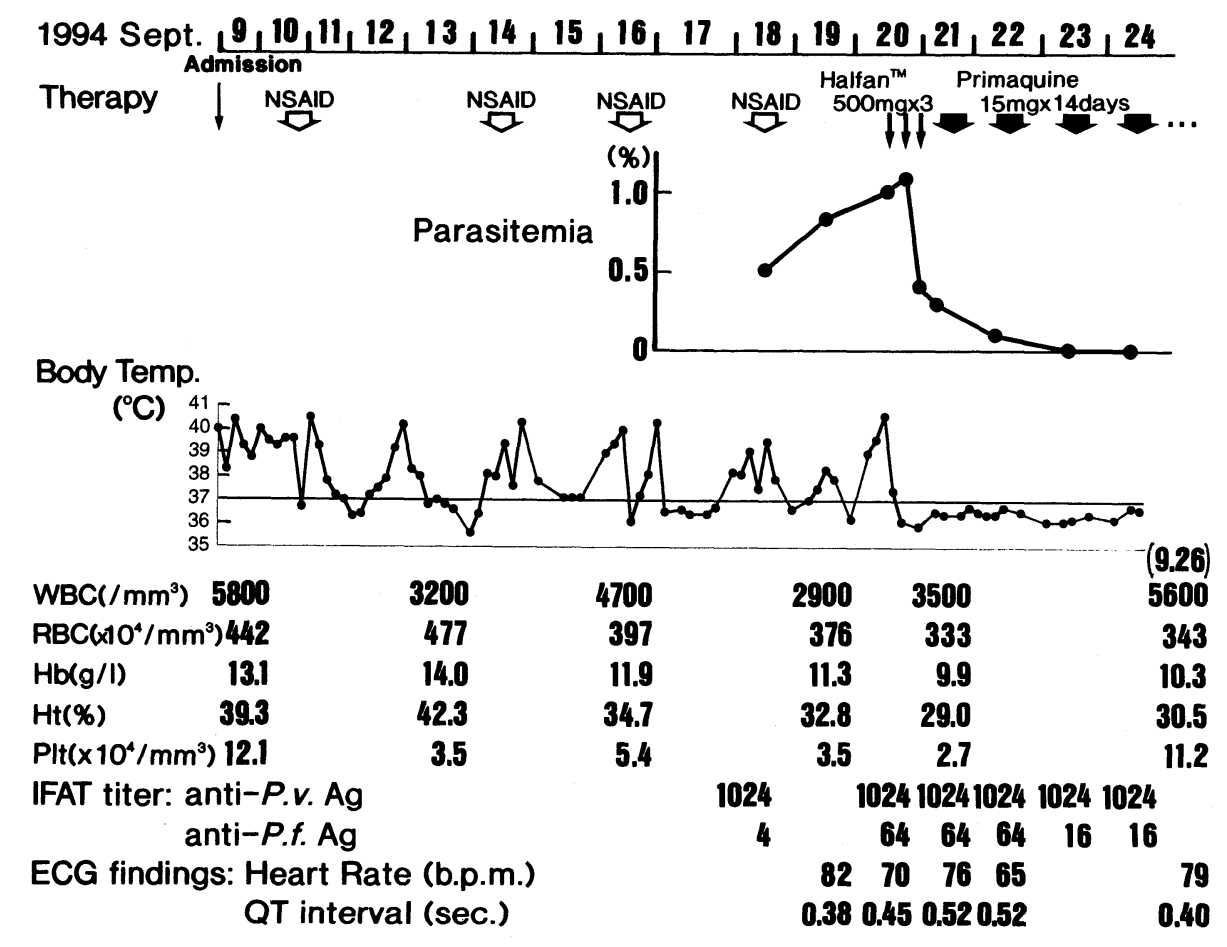


Fig. 2 The patient's electrocardiogram on September 21

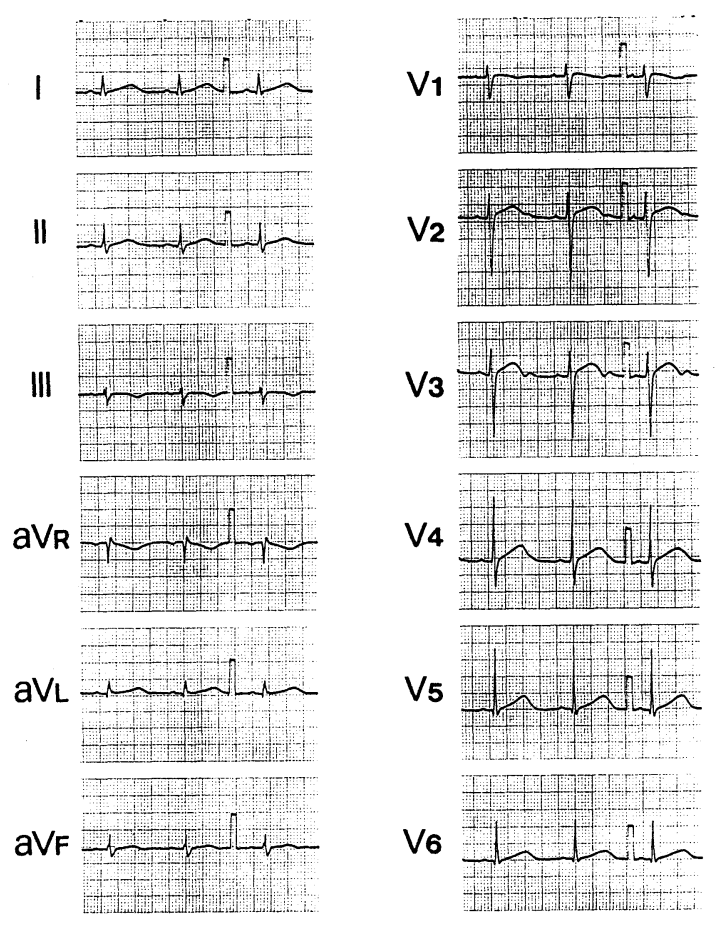

Fig. 3 The patient's electrocardiogram on September 26

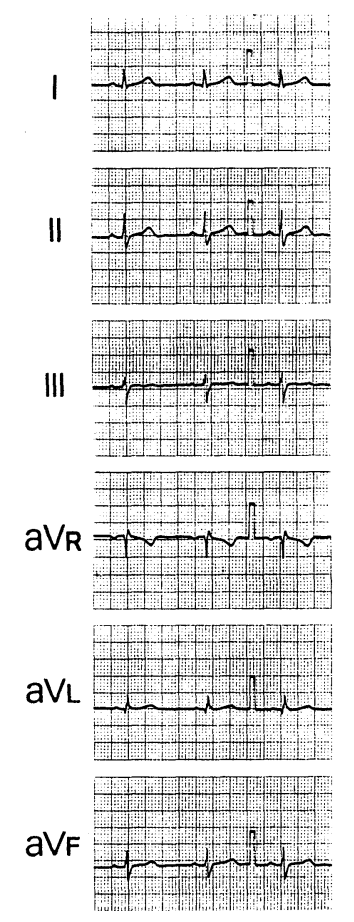

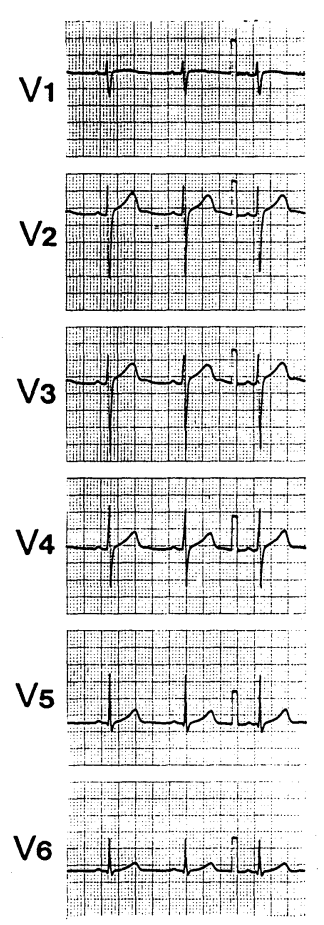

\section{Discussion}

Halofantrine is an antimalarial drug which is effective against all species of Plasmodium, very well tolerated, and has a simple dosage regimen. It belongs to a class of compounds, the phenanthrene-methanols, which do not share chemical structure with any other antimalarials, and is therefore particularly effective in the treatment of drug-resistant falciparum malaria ${ }^{3}$. Although resistance of vivax malaria to chloroquine has occurred only occasionally so far, it is now firmly established in the island of New Guinea (Indonesia and Papua New Guinea) ${ }^{14,15}$. Therefore, it has to be taken into consideration that $\operatorname{Halfan}^{\circledR}$ can be the drug of first choice even for patients who have contracted vivax malaria. In P. vivax malaria, the mean parasite clearance time was 62 hours and the mean fever clearnace time was 42 hours after treatment by Halfan ${ }^{\circledR}$. The patient reported here was apparently thought to have been successfully treated; parasites were cleared by 69 hours and the fever fell to normal in 9 hours, without any signs or symptoms of the side effects of the drug. However, ECG revealed by dysrythmiasis with prolongation of the QT intervals following treatment with Halfan ${ }^{\circledR}$. These ECG changes were reported to be brought about by the increased myocardial concentrations of halofantrine or its biologically active metabolite ${ }^{9}$, but not associated with desbutylhalofantrine (one of the metabolites of halofantrine) ${ }^{12}$. And the fact that these effects are similar to those of quinine $^{16)}$ suggests caution in treating patients previously administered quinine (or vice versa) ${ }^{12)}$. In accordance with advice from the pharmaceutical company, WHO announced a drug alert for halofantrine ${ }^{13)}$ to reduce the cardiac effects of the drug to a minimum: a) It is contraindicated in patients with a family history of congenital QT prolongation. b) It is not recommended for usage in combination with drugs or clinical conditions known to prolong the QT interval or in patients who may suffer from thiamine deficiency. c) It should not be administered to patients with severe 
electrolyte imbalance. d) The treatment should not exceed the recommended total dosage of $24 \mathrm{mg} /$ $\mathrm{kg}$ given as $8 \mathrm{mg} / \mathrm{kg} 3$ times at 6 -hour intervals. e) It should be administered on an empty stomach (i.e. not given in association with food). f) It should only be used as emergency self-medication for presumptive therapy in those patients known to have normal QT intervals. Abiding by the conditions mentioned above, we experienced the first case of vivax malaria in a Japanese patient who showed abnormal ECG findings following treatment with halofantrine. Further careful studies on individual Japanese patients to confirm its efficacy or tolerance should be required, before halofantrine is generally used in Japan.

\section{Acknowledgement}

A summary of the present report was orally presented at the 6th meeting of of Clinical Parasitology (June 1995, Tokyo). The authors are grateful to Dr. Takeo Saoshiro (National NishiSaitama Chuo Hospital), Dr. Gohta Masuda (Tokyo Metropolitan Komagome Hospital) and Prof. Hiroshi Ohtomo (The Jikei University School of Medicine) for helpful discussion.

\section{Referecnes}

1) WHO: Population at risk, World malaria situation in 1992, Weekly Epidemiological Record 69: $309,1994$.

2) Ohtomo, H., Takeuchi, T., Masuda, G., Akao, M., Takada, S., Araki, T., Tusji, M. \& Tanaka, H.: Malaria incidence in Japan for past 5 years. Jpn. J. Parasitol. 42: 137, 1993.

3) SmithKline Beecham Pharmaceuticals: Halfan product information, SB House, Middlesex, UK, 1992.

4) Kano, S., Yodonawa, S. \& Suzuki, M.: Two cases of vivax malaria treated with halofantrine. Jpn. J. Trop. Med. Hyg. 20: 72, 1992.

5) Masuda, G., Ajisawa, A., Negishi, M., Yamaguchi, T., Kano, S. \& Suzuki, M.: A case of mix infection with Plasmodium falciparum and P. malariae treated with halofantrine. Clin. Parasitol. 3: 38-40, 1992.

6) Yodonawa, S., Kano, S., Saito, M., Yamaguchi, T. \& Suzuki, M.: An imported case of vivax malaria treated with halofantrine. Jpn. J. Trop. Med. Hyg. 20: 299-303, 1992.

7) Kano, S., Masuda, G., Kubo, Y., Saito, M., Yamaguchi, T. \& Suzuki, M.: Four imported cases of falciparum malaria successfully treated with halofantrine. Jpn. J. Trop. Med. Hyg. 21: 245-249, 1993.

8) Obana, M., Matsuoka, Y., Irimajiri, S., Kano, S. \& Suzuki, M.: A case of Plasmodium falciparum malaria successfully treated with halofantrine. J. Jpn. A. Inf. D. 68: 399-402, 1994.

9) Nosten, F., Ter Kuile, F.O., Luxemburger, C., Woodrow, C., Kyle, D.E., Chongsuphajaisiddhi, T. \& White, N.J.: Cardiac effects of antimalarial treatment with halofantrine, Lancet 341: 1054-1056, 1993.

10) Castot, A., Rapoport, P. \& Le Coz, P.: Prolonged QT interval with halofantrine, Lancet 341, $1541,1993$.

11) Monlun, E., Pillet, O., Cochard, J.F., Favarel Garrigues, J. Cl. \& Le Bras, M.: Prolonged QT interval with halofantrine, Lancet 341: 1541-1542, 1993.

12) Karbwang, J., Bangchang, K. Na., Bunnag, D. \& Harinasuta, T.: Cardiac effect of halofantrine, Lancet 342: 501, 1993.

13) WHO: Drug alert: halofantrine-Change in recommendations for use, Weekly Epidemiological Record 68: 269-270, 1993.

14) WHO: Malaria resistance to drugs, World malaria situation in 1992, Weekly Epidemiological Record 69: 311 , 1994.

15) Murphy, G.S., Basri, H., Andersen, P.E.M., Bangs, M.J., Mount D.L., Gorden, J., Lal, A.A., Purwokusumo, A.R., Harjosuwarno, S., Sorensen, K. \& Hoffman, S.L.: Vivax malaria resistant to treatment and prophylaxis with chloroquine, Lancet 341: 96-100, 1993.

16) Karbwang, J., Davis, T.M.E., Looareesuwan, S., Molunto, P., Bunnag, D. \& White, N.J.: A comparison of the pharmacokinetic and pharmacodynamic properties of quinine and quinidine in healthy Thai males, Br. J. Clin. Pharmacol. 35: 265-271, 1993. 
ハロファントリンによる治療後, 心電図上に一過性の QT 時間 延長が認められた三日熱マラリア日本人症例

${ }^{12}$ 群馬大学医学部寄生虫学教室, ${ }^{2}$ 国立西埼玉中央病院消化器科, 3)群馬大学医学部臨床検査医学教室

狩野 繁之 ${ }^{1)}$ 林 昭太 ${ }^{21}$ 神田 亨勉 ${ }^{3)}$ 鈴木 守 ${ }^{11}$

\section{要旨}

ハロファントリンは1984年よりマラリアの臨床 治験が開始され，本邦においてもその優れた有効 性が報告されてきている。しかしながら1993年よ り，本薬剤投与後の心電図上の QT 時間延長を伴 う心筋に対する重篤な障害が諸外国において報告 されだした。われわれは三日熱マラリアの22歳の
日本人男性に，患者への説明とその同意を得てハ ロファントリンを投与したところ, 自覚的な副作 用は認められることなく患者は治瘜に至ったが, 薬剤投与後 2 日目， 3 日目に心電図上に QT 時間 の延長を一過性に認めた。本報告はハロファント リンの副作用と考元られる心電図上の変化を, 日 本人で初めて確認した症例と考元られる。 